\title{
Pediatric Headaches: One year of Observation from A Tertiary Center
}

\author{
Pediatrik Baş Ağrısı: Üçüncül Bir Merkezin Bir Yıllık Gözlemi
}

\author{
Ozlem YAYICI KOKEN¹, Betul DUNYA², Ayse Yasemin CELIK², Deniz YILMAZ², \\ Aysegul Nese CITAK KURT ${ }^{2,3}$
}

1 SBU, Antalya Education and Research Hospital, Department of Pediatric Neurology, Antalya, Turkey
${ }^{2}$ Ankara City Hospital, Childrens' Hospital, Department of Pediatric Neurology, Ankara, Turkey
${ }^{3}$ Y Ildırm Beyazit University, Faculty of Medicine, Department of Pediatric Neurology, Ankara, Turkey

\section{ABSTRACT}

Objective: This study aims to investigate the demographic, clinical features of children and adolescents with headaches which is one of the most common reason for referral to pediatric neurology clinics in addition to elucidating the frequency of primary and secondary headaches as well as their management.

Material and Methods: We retrospectively reviewed the medical reports of children and adolescents who were referred to Ankara City Hospital, Department of Pediatric Neurology between December 2019 and December 2020.

Results: During the study period, 236 (86.8\%) children, and adolescents were diagnosed with primary headaches and 36 (13.2\%) were diagnosed with secondary headaches. Tension headaches were the most frequent (71.2\%) type of primary headaches while headache or facial pain attributed to disorders of the cranium, neck, eyes, ears, nose, sinuses, teeth, mouth or other facial or cervical structure were the most frequent (38.8\%) type of secondary headaches. All patients with secondary headaches had at least one red flag while 23 (63.8\%) patients had 2 or more red flags. Magnetic resonance imaging was diagnostic in 58.3\% of the patients while EEG was diagnostic in 6\% of the patients.

Conclusion: Pediatric patients presenting with headaches should be carefully examined to diagnose and treat the causes of secondary headaches which can be life-threatening and require urgent treatment. On the other hand, accurate diagnosis is very important in primary headaches which constitute more than $80 \%$ of all headaches and have detrimental effects on life quality as a result of refraining from daily activities.

Key Words: Headache, Primary headache, Secondary headache

ÖZ

Amaç: Çocuk Nörolojisi polikliniklerine en sık başvuru yakınmalarından olan baş ağrılı çocuk ve adolesanların, demografik, klinik Özellikleri yanısıra primer ve sekonder baş ağrısı sıklığı ve yönetiminin ortaya konulması amaçlanmıştır.

Gereç ve Yöntemler: Aralık 2019-2020 tarihleri arasında Ankara Şehir Hastanesi, Çocuk Nörolojisi Kliniği'ne başvuran çocuk ve adolesanların tıbbi kayıtları retrospektif olarak değerlendirildi.

\section{(1)}

YAYICI KOKEN O

DUNYA B

CELIK AY

YILMAZ D

CITAK KURT AN
0000-0003-2112-8284 0000-0002-3900-8996 $0000-0002-6734-0427$ :0000-0002-0789-8955 $0000-0002-7277-3550$
Conflict of Interest / Çıkar Çatışması: On behalf of all authors, the corresponding author states that there is no conflict of interest.

Ethics Committee Approval / Etik Kurul Onayi: The study was approved by the Regional Ethics Committee (Ankara City Hospital, Clinical Studies E2-21-287) and the study was conducted by the Declaration of Helsinki.

Contribution of the Authors / Yazarların katkısI: YAYICI KOKEN O: Constructing the hypothesis or idea of research and/or article, Planning methodology to reach the Conclusions, Organizing, supervising the course of progress and taking the responsibility of the research/study, Taking responsibility in patient follow-up, collection of relevant biological materials, data management and reporting, execution of the experiments, Taking responsibility in logical interpretation and conclusion of the results, Taking responsibility in necessary literature review for the study, Taking responsibility in the writing of the whole or important parts of the study, Reviewing the article before submission scientifically besides spelling and grammar. DUNYA B

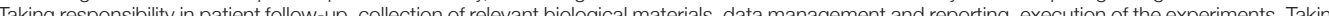
Takng esponsist in materials, data management and reporting, execution of the experiments, Taking responsibility in necessary literature review for the study. YILMAZ $\boldsymbol{D}$ : Organizing, supervising the course of progress and taking the responsibility of the research/study, Reviewing the article before submission scientifically besides spelling and grammar. CITAK KURT AN: Constructing the hypothesis or idea of research and/or article, Planning methodology to reach the Conclusions, Organizing, supervising the course of progress and taking the responsibility of the research/study, Taking responsibility in patient follow-up, collection of relevant biological materials, data management and reporting, execution of the experiments, Taking responsibility in logical interpretation and conclusion of the results, Taking responsibility in necessary literature review for the study, Reviewing the article before submission scientifically besides spelling and grammar.

How to cite / Atıf yazım şekli : Yayici Koken O, Dunya B, Celik AY, Yilmaz D, Citak Kurt AN. Pediatric Headaches: One year of Observation from A Tertiary Center. Turkish J Pediatr Dis 2021;15:488-493.
Correspondence Address / Yazışma Adresi:

\section{Ozlem YAYICI KOKEN}

SBU, Antalya Education and Research Hospital,

Department of Pediatric Neurology, Antalya, Turkey

E-posta: drozlemkoken@gmail.com
Received / Geliş tarihi : 02.05.2021 Accepted / Kabul tarihi : 25.05.2021

Online published 14.09.2021

Elektronik yayın tarihi

DOI:10.12956/tchd.926946 
Bulgular: Primer baș ağrısı tanııı alan 236 (\%86.8), sekonder baș ağrısı tanısı alan 36 (\%13.2) çocuk ve adolesan olduğu; primer baş ağrısı grubu içinde en sık gerilim tipi baș ağrısı (\%71.2), sekonder baș ağrısı için baș, boyun, göz, kulak, burun, sinüsler, diș dudak veya diğer yüz veya servikal yapılardan kaynaklanan bozukluklara bağlı baş ağrısı grubunda (\%38.8) hasta başvurusu olduğu saptandı. Sekonder baş ağıısı tanısı alan hastaların tamamı en az 1 kırmızı bayrak bildirmiş olup 23 hastada (\%63.8) 2 ve daha fazla sayıda kırmızı bayrak saptandı. Her iki grupta da en sık bildirilen kırmızı bayrak; lokalize baş ağrısıydı. Hastaların \%58.3'ünde MRG, \%6'sında EEG tanısal özellik göstermiştir.

Sonuç: Baş ağrılı pediatrik hasta popülasyonun hayatı tehdit eden ve acil tedavi gerektiren sekonder baş ağrısı nedenlerinin tespiti için hastanın ilk değerlendirmesinden itibaren klinik özelliklerinin dikkatle yönetilmesi ve değerlendirilmesi önerilir. Diğer taraftan; hayat kalitesini olumsuz etkileyen, günlük aktivitelerden çekilmeye neden olan ve hastaların \% 80'den fazlasını oluşturan primer baş ağrıarı için tanı büyük önem taşımaktadır.

Anahtar Sözcükler: Baş ağrısı, Primer baş ağrısı, Sekonder baş ağıısı

\section{INTRODUCTION}

Headaches are among the most frequent causes of referral in the practice of pediatric neurology. Given the fact that 1 out of 10 people experiences headaches at least once in a lifetime, this is expected (1). Headaches affect approximately $60 \%$ of children and adolescents between 2 and 18 years of age and are more frequent during adolescence $(2,3)$. Contrary to other neurologic diseases or disorders, there is no objective laboratory diagnosis that supports or proves this common neurological problem. Headaches are defined and classified according to "International Classification of Headache Disorders" which was proposed by the Committee of the International Headache Society and was last revised in 2018 (4). This classification categorizes headaches as primary and secondary (4). As in all age groups; demographical, clinical findings and neurological examination in addition to neuroimaging and electrophysiological studies which are used for differential diagnosis are important in the pediatric age group. A correct definition and classification is the sole factor that governs patient management.

A patient with a headache visits emergency services, primary care physicians, or pediatric clinics more often than pediatric neurology clinics. The most important point is the detection of a secondary headache that requires urgent treatment in the first visit by the clinician. On the other hand, chronic headaches hamper school attendance, cause loss of daily activities, insufficient participation in regular activities, loss of productivity, and significant deterioration of life quality (2). Because of these reasons, all headache types require appropriate and urgent medical management.

This study aims to evaluate the demographic, clinical, and laboratory findings of children who were referred to and/ or consulted with the pediatric neurology clinic due to headaches in a one-year in addition to reviewing the frequency, symptomatology, and diagnostic approach to their headaches.

\section{MATERIAL and METHODS}

This retrospective, descriptive, single-center study was conducted at the Department of Pediatric Neurology of Ankara
City Hospital in Ankara, Turkey. The study was approved by the Regional Ethics Committee (Ankara City Hospital, Clinical Studies E2-21-287) and the study was conducted by the Declaration of Helsinki.

All the patients who applied for the complaint of headache between December 2019 and December 2020 to Ankara City Hospital, Children's Hospital, Department of Pediatric Neurology were evaluated.

To obtain a homogenous dataset, clinical records of patients with headaches who were assessed using a standardized and structured form were retrospectively evaluated. A patient with a headache was excluded from the study if he, or she had incomplete records, known disorders related to the headache, or known structural intracranial disorders. Age, sex, patient and family history for primary headaches as well as duration, localization, type, characteristics of the headaches, concomitant clinical findings, and the existence of red flags were evaluated. The usefulness of cranial magnetic resonance imaging (MRI) and electroencephalography (EEG) findings in elucidating the headache etiology was also investigated.

In our clinic, primary and secondary headaches are classified according to the International Classification of Headache Disorders (revised 2018 criteria, designated as ICHD-3) which was proposed by the Committee of the International Headache Society (4). Based on these criteria, primary headaches were classified as migraine, tension-type headache, trigeminal autonomic cephalalgias, and other primary headache disorders.

Secondary headaches were classified as headaches attributed to trauma or injury to the head and/or neck, headaches attributed to non-vascular intracranial disorder, headaches attributed to infection, headaches attributed to cranial and/ or cervical vascular disorder, headaches attributed to a substance or its withdrawal, headaches attributed to disorder of homeostasis, headaches attributed to psychiatric disorder and finally headaches or facial pain attributed to disorder of the cranium, neck, eyes, ears, nose, sinuses, teeth, mouth or other facial or cervical structures.

\section{Statistical Analyses}

Data analyses were performed using SPSS for Windows, version 22.0 (IBM Corp., Armonk, NY, USA). The Kolmogorov- 
Smirnov test was used to determine whether the distribution of continuous variables was normal or not. The Levene test was used to evaluate the homogeneity of the variances. Continuous data were described as the mean \pm SD. Categorical data were described as the number of cases (\%). Statistical analysis of the differences in the non-normally distributed variables between 2 independent groups were carried out using the Mann-Whitney $U$ test, while differences in the non-normally distributed variables among more than 2 independent groups were analyzed using the Kruskal Wallis test. When the P-value from the Kruskal-Wallis test was statistically significant, the post hoc Conover non-parametric multiple comparison test was used to determine which group differed from the others. $p<$ 0.05 was accepted as statistically significant.

\section{RESULTS}

The mean age of the patients was $12.8 \pm 3.6$ years old and $66 \%$ $(n=180)$ were girls. Data from 273 children and adolescents were retrospectively evaluated. The monthly distribution of admittances is summarized in Figure. The greatest number of admittances were observed in July.

Two hundred and thirty-six (86.8\%) patients were diagnosed with a primary headache while 36 (13.2\%) patients were diagnosed with a secondary headache. Groups were similar concerning age and gender. The distribution of primary headache subtypes was as follows: $71.2 \%(n=219)$ tension-type headaches, $7.2 \%$ $(n=17)$ migraine headaches and $21.6 \% \quad(n=51)$ unclassified headaches. Six (35.3\%) patients and adolescents with a migraine described an aura and were diagnosed as migraines with aura. Family history for primary headaches in first and second-degree relatives was positive in $40.4 \%(n=91)$ of the patients with primary headaches and 11\% $(n=10)$ of these patients had migraines. A history of primary headaches was positive in $76.5 \%(n=13)$ of the patients with migraines while family history for primary headaches was positive in $35.6 \%$ $(n=78)$ of the patients with tension-type headaches.

Patients with secondary headaches are summarized in Table I. Of 4 patients with secondary headaches, 2 patients had arteriovenous malformations, one had a cavernous angioma and one had a cerebral venous thrombosis which constituted the patient group with headaches attributed to cranial and/or cervical vascular disorders. Only one patient had a persistent headache attributed to traumatic injury to the head, and a patient who was using antipsychotic drugs was diagnosed with a headache attributed to a psychotic disorder. In the three patients who had headaches attributed to infections, two had acute headaches attributed to other systemic infections and one patient had a persistent headache attributed to past bacterial meningitis. There were no patients with a headache attributed to a substance or its withdrawal.

One patient who had hypothyroidism on admission and one patient who had arterial hypertension were included in the headache attributed to a disorder of homeostasis group. The majority of the patients belonged to the headaches or facial pain attributed to a disorder of the cranium, neck, eyes, ears, sinuses, teeth, mouth, or other facial and cervical structure groups where 10 patients had acute, chronic, or recurrent rhinosinusitis which responded to treatment while 4 patients had myopia which improved with prescription glasses. Ten patients were in the headaches attributed to non-vascular intracranial disorders group and of these, 6 had idiopathic intracranial hypertension, 3 had headaches accompanied by abnormal EEG recordings presumed to be ictal epileptic and/ or associated with an epileptic seizure which benefited from antiepileptic treatment while 1 patient had a Chiari type I malformation.

Comparison of primary and secondary headache patients concerning pain characteristics is given in Table II. Squeezing and non-specific headaches were more common in patients with primary headaches while throbbing headaches were more common in patients with secondary headaches $(p=0.033)$.

Phonophobia was present in $47 \%(n=108)$ of the patients with primary headaches and $42.9 \%(n=15)$ of the patients with secondary headaches while photophobia was present in $43 \%(n: 99)$ of the primary headache patients and $28.9 \%(n=10)$ of the patients with secondary headaches ( $p=0.651$ and 0.105 , respectively). Nausea was reported by $38.4 \%(n=86)$ of the patients with primary headaches and $12.1 \%(n=4)$ of patients with secondary headaches while $10.1 \%(n=23)$ of the patients with primary headaches and $12.2 \% \quad(n=4)$ with secondary

Table I: Etiological distribution of secondary headaches in children and adolescents.

\begin{tabular}{l|l|}
\hline \multicolumn{1}{|c}{ Etiology of secondary headache $(\mathbf{n}: 36)$} & $\mathbf{n}(\%)$ \\
\hline Headache attributed to cranial and/or cervical vascular disorders & $4(11.1)$ \\
\hline Headache attributed to non-vascular intracranial disorders & $10(27.7)$ \\
\hline Headache attributed to infection & $3(8.3)$ \\
\hline Headache or facial pain attributed to disorder of the cranium, neck, eyes, ears, nose, sinuses, teeth, \\
mouth or other facial or cervical structure
\end{tabular}


Table II: Comparison of headache characteristics.

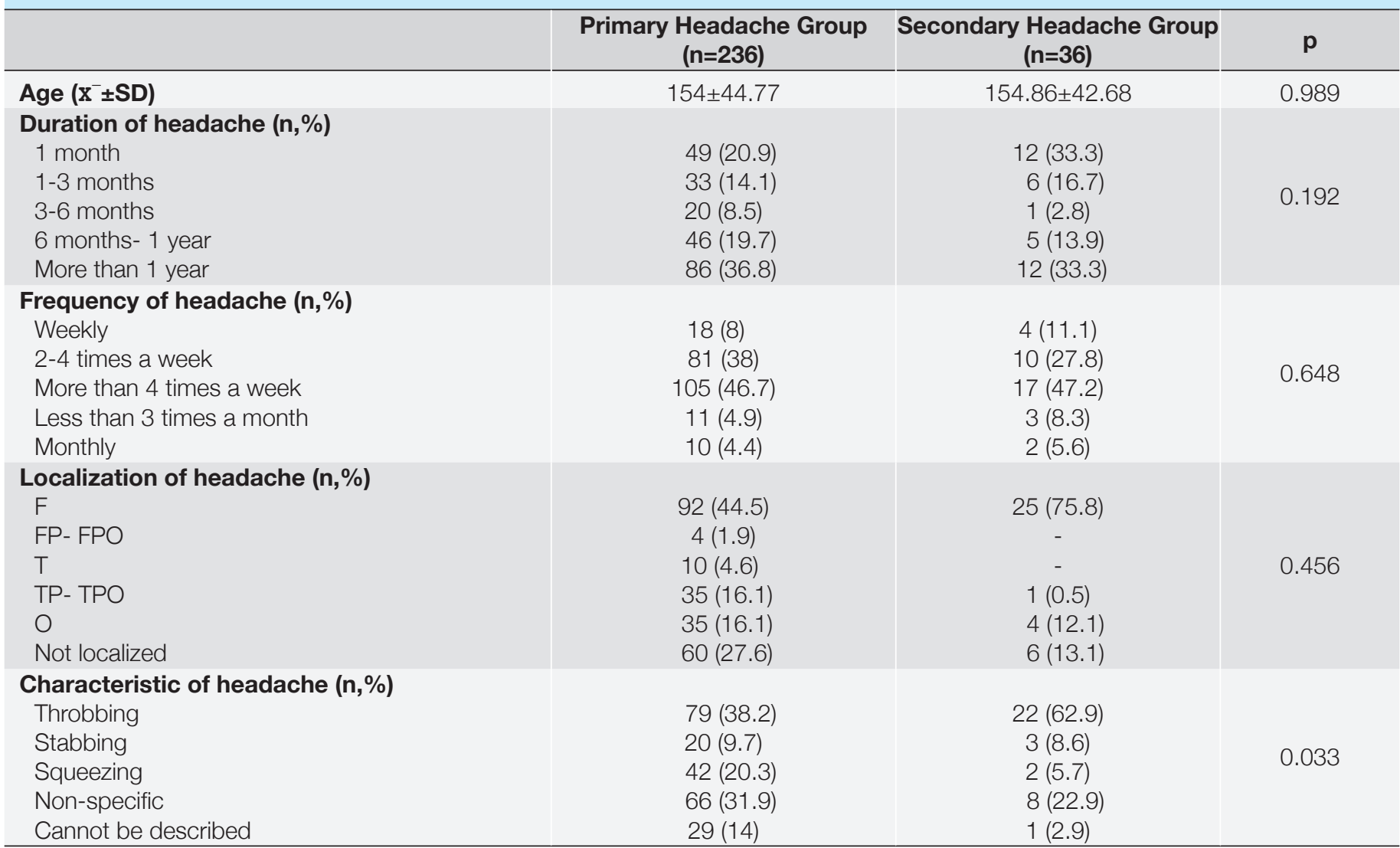

*F: frontal, $\boldsymbol{F P :}$ frontoparietal, $\boldsymbol{F P O}$ : frontoparietooccipital, T: temporal, TP: temporoparietal, TPO: temporoparietooccipital, O: occipital

Table III: Distribution of red flags according to headache types.

\begin{tabular}{|c|c|c|}
\hline & $\begin{array}{l}\text { Primary Headache Group } \\
(n=236)(n, \%)\end{array}$ & $\begin{array}{l}\text { Secondary Headache Group } \\
(n=36)(n, \%)\end{array}$ \\
\hline Systemic symptoms & $14(6.1)$ & - \\
\hline History of malignancy & $2(0.8)$ & - \\
\hline Existence of acute neurologic deficit & - & $1(2.9)$ \\
\hline Positional headache & $8(3.4)$ & $4(11.4)$ \\
\hline Sudden onset & $5(2.1)$ & $2(5.7)$ \\
\hline New onset headache or a new pattern & $15(6.4)$ & $2(5.7)$ \\
\hline $\begin{array}{l}\text { Precipitated by sneezing, coughing, exercise or } \\
\text { Valsalva maneuver }\end{array}$ & $3(1.3)$ & $7(19.4)$ \\
\hline Existence of papilledema & - & $4(11.4)$ \\
\hline Progressive headache & $8(3.4)$ & $3(8.6)$ \\
\hline Localized headache & $137(58)$ & $29(80.5)$ \\
\hline Headache disrupting sleep & $5(2.1)$ & \\
\hline Existence of accompanying epileptic seizure & - & $1(2.9)$ \\
\hline Headache accompanied by vomiting & $23(9.7)$ & $4(11.1)$ \\
\hline
\end{tabular}

headaches ad reported vomiting $(p=0.003$ and $p=0.759$, respectively).

At least one red flag was reported in 165 (69.9\%) patients with primary headaches however, 58\% ( $n=137)$ of these patients reported localized headaches (Table III). Forty-two patients $(17.7 \%)$ had more than one red flag. All patients with secondary headaches had at least one red flag while 23 (63.8\%) had two or more red flags.

Limitation of daily activities (socializing with friends, visiting crowded places, or difficulty attending school) was present in $22 \%(n=52)$ of the patients with primary headaches and $25 \%(n=9)$ of the patients with secondary headaches with no 
statistically significant difference between groups $(p=0.690)$. School attendance problems were present in $10.5 \%(n=25)$ of the patients with primary headaches and $19.4 \%(n=7)$ of the patients with secondary headaches $(p=0.169)$. Disrupted sleep patterns and increased screen exposure during the pandemic were reported by $31.7 \%(n=75)$ of the patients with primary headaches and $44.4 \%(n=16)$ of the patients with secondary headaches.

MRI was planned for $77.2 \%(n=210)$ of all patients and was performed for 174 (73.7\%) patients with primary headaches and all patients with secondary headaches. MRI played a key role in the diagnosis in 21 of 36 (58.3\%) patients with secondary headaches. Fundus examination revealed no papilledema in two (33.3\%) of 6 patients who were diagnosed with pseudotumor cerebri as a result of MRI scanning.

EEG was planned for $18.4 \%$ ( $n=50)$ of all patients; 3 (6\%) patients with secondary headaches had epileptic activity and reported improvement in their headaches after antiepileptic treatment given for ictal headache.

\section{DISCUSSION}

Although the majority of headaches in childhood and adolescence are primary headaches, secondary headaches which are life-threatening and/or can be completely cured must be ruled out during the initial evaluation (1-3,5-7). Symptoms called red flags which can be used to differentiate between these two types of headaches in addition to the ophthalmologic examination, electrophysiologic evaluation and neuroimaging features are of great importance (5-12).

Our study population consisted of $86.8 \%$ primary and $13.2 \%$ secondary headaches. The most frequent type of primary headaches as tension-type headache while headache or facial pain attributed to disorder of the cranium, neck, eyes, ears, nose, sinuses, teeth, mouth, or other facial or cervical structure secondary to rhinosinusitis were more prominent in the secondary headache group. In a case series where 810 pediatric patients complaining of headaches underwent MR imaging, the frequency of secondary headaches was reported as $17 \%$ while primary headaches consisted $83 \%$ of the study population (11). The reason for more frequent secondary headaches in this study was the limitation of evaluation to patients with cranial MR imaging. Similar to our results, the most frequent etiology of secondary headaches were rhinosinusitis and rhinitis (11). On the other hand, etiologies requiring urgent medical or surgical treatment such as encephalitis, meningitis, intracranial tumors or mass lesions or acute hydrocephalus were not observed. The patients may have preferred emergency services over clinics during the COVID-19 pandemic which was ongoing during the study period or they may have been directed to the related department which could explain the frequency of secondary headaches being lower than expected.
The second most frequent cause of secondary headaches is pseudotumor cerebri and more than $60 \%$ of these patients can be diagnosed after a fundus examination, which emphasizes the importance of ophthalmologic examination.

In a series of 478 cases from our country, $45.6 \%$ of the patients were diagnosed with migraine, $33.3 \%$ were diagnosed with tension-type headaches while $8.8 \%$ were diagnosed with secondary headaches (5). In another series consisting of 100 patients from our country, migraine frequency was $58 \%$ while tension-type headache frequency was $25 \%$ (9). The most common causes of headaches were reported as migraine (37.3\%) and tension-type headaches (25\%) in another study. The three studies mentioned had evaluated children and adolescents with headaches before 2016 and as such, had not used the ICHD-3 published in 2018 and used in our study. Similar results pointing to migraine being more frequent exist in the literature $(2,3,10)$. In a study that investigates the period when ICHD-3 or ICHD-2 criteria were used, 1056 patients were evaluated and $43 \%$ were diagnosed with migraine, $35 \%$ had a tension headache, and 22 had other types of primary headaches (2). In this aspect, our findings contradict the literature since tension-type of primary headaches is more frequent. This could be because our study involves the COVID-19 pandemic period and this period is associated with difficulty/failure in stress management. In our study, there was no statistically significant difference concerning the duration, frequency, and localization of symptoms. Nausea was more frequent in primary headaches and these headaches had a squeezing characteristic. Secondary headaches were more prominently localized in the frontal region, had a throbbing characteristic and although average ages were statistically similar, we detected a higher incidence of nonspecific and hard to describe headaches. A red flag was detected in $100 \%$ of the secondary headaches and $69 \%$ of the primary headaches with localized headache being the most prominent. Red flags were reported in $85.2 \%$ of the patients complaining of headaches. Despite this fact, a cranial MRI was planned in $77 \%$ of the patients. This reinforces the notion that MRI is planned to depend on the experience of the clinician in addition to clinical and laboratory data even though red flags are warning signs for secondary headaches. Cranial MRIs were planned for $85.2 \%$ of the patients and led to a definitive diagnosis in $10.1 \%$ of the patients.

In a study where 481 children with headaches were evaluated, cranial MRI scans were performed for $85 \%$ of the patients and a pathology that could explain the headache was detected in $31.4 \%$ of the patients (5). In another study, cranial MRI was diagnostic in $7.6 \%$ of the patients (9). The diagnostic value of MRI can be different even though it is planned at the same rate. This could be explained by several facts such as the clinical experience of the clinician, heterogeneous patient selection due to concerns of the parents or the clinician even when atypical headache patterns or neurologic anomalies are an absent or a limited selection of patients based solely on the existence of 
red flags. EEG, which is another diagnostic test in the pediatric neurology practice, was diagnostic in $1.1 \%$ of our patients. Similar to the literature, the contribution of EEG to the diagnosis of headache is rather limited $(5,14)$.

To obtain homogeneity in our patient population, we used a structured anamnesis form in the clinic where the patients were evaluated. The number of patients who were recruited in this retrospective study is lower than the number of patients admitted with a headache since the patients who were not evaluated with a structured anamnesis and those with incomplete file records were excluded. On the other hand, the number of admissions was highest in months with fewer COVID-19 precautions. We believe that there has been a decline in the number of patients due to a lower number of clinics available secondary to the COVID-19 pandemic and the patients have been reluctant to visit our center which has a high number of COVID-19 patients. We believe that the relatively high number of unclassified headaches in the primary headache group can be explained by the retrospective nature of this study.

Secondary headaches, which made up $13.2 \%$ of our study population, should be ruled out in the management of pediatric headache patients. Additionally, the characteristic of headaches and the existence of red flags should be carefully examined and pathologies that require urgent medical treatment and even surgery should be detected before directing the patient to a higher center.

\section{REFERENCES}

1. Krogh $A B$, Larsson $B$, Linde $M$. Prevalence and disability of headache among Norwegian adolescents: A cross-sectional school-based study. Cephalalgia 2015; 35: 1181-91.

2. Jeong, YJ, Lee YT, Lee IG, Han JY. Primary headaches in children and adolescents - experiences at a single headache center in Korea. BMC Neurology 2018;18:70
3. Abu-Arafeh I, Razak S, Sivaraman B, Graham C. Prevalence of headache and migraine in children and adolescents: a systematic review of population-based studies. Developmental Medicine and Child Neurology 2010; 52:1088-97

4. Headache Classification Committee of the International Headache Society (IHS) The International Classification of Headache Disorders, 3rd edition. Cephalalgia 2018; 38:1-211.

5. Gurkas E, Karalok ZS, Taskın BD, Aydogmus U, Yılmaz C, Bayram $\mathrm{G}$. Brain magnetic resonance imaging findings in children with headache. Archivos Argentinos de Pediatría 2017;115:349-55.

6. Dao JM, Qubty W. Headache Diagnosis in Children and Adolescents. Current Pain Headache Reports 2018; 22:17.

7. Blume HK. Childhood Headache: A Brief Review. Pediatrics Annals 2017;46:155-65.

8. Gürkaş E, Karalök Z, Taşkın B, Aydoğmuș Ü, Yılmaz C. Clinical Features and Eeg Findings in Childhood Migraine and Tension Type Headache. Turkish J Pediatr Dis 2017;11:165-70.

9. Yılmaz D, Gökkurt D, Tayfur A. Evaluation of Childhood Headache in an Outpatient Pediatric Neurology Clinic. Turkish J Pediatr Dis 2016;10:162-5.

10. Langdon R, DiSabella MT. Pediatric Headache: An Overview. Curr Probl Pediatr Adolesc Health Care 2017;47:44-65.

11. Yayıcı Köken Ö, Danış A, Yüksel D, Aksoy A, Öztoprak Ü, Aksoy E. Pediatric headache: Are the red flags misleading or prognostic? Brain and Development 2021; 43:372-9.

12. Straube A, Andreou A. Primary headaches during lifespan. J Headache Pain 2019;20:35.

13. Ekici A, Yimenicioğlu S, Carman K. Kocak O, Yarar C, Yakut A. Evaluation of headache in children: a retrospective study. Eur Res J2015;3;136-40.

14. Lewis DW, Koch T. Headache evaluation in children and adolescents: when to worry? When to scan?. Pediatric Annals 2010; 39:399-406.

15. Raucci U, Della Vecchia N, Ossella C, Paolino MC, Villa MP, Reale A, et al. Management of Childhood Headache in the Emergency Department. Review of the Literature. Frontiers Neurology 2019; 23;10: 886 . 